\title{
Kriminologers bruk av teori: Svar til Leif Petter Olaussen
}

\author{
Nicolay B. Johansen, IKRS, UiO*
}

Såkalt teori er hjelperedskaper for å tenke. Innen samfunnsvitenskapen er man opptatt av at metodebruken skal være pålitelig og gyldig. Men hvorfor skal ikke måten man bruker tenkeredskaper være like viktig? Det går en grense mellom det å bruke overgripende fortellinger om samfunnsutviklingen (teori), til på den ene siden å legitimere et synspunkt, og på den annen side å klargjøre et resonnement. Lettvint teoribruk lgger til rette for det førstnevnte. Olaussen har i sine artikler om kriminalitetens eksistens ikke utvist noen tegn til å bruke teori til å legitimere bestemte synspunkter, men den uklarhet som følger av hans måte å behandle teori etterlater rom for andre til å gjøre det.

De siste årene har jeg arbeidet med migrasjonsrelaterte spørsmål. En forfatter som brukes mye på dette feltet er den italienske filosofen Giorgio Agamben. Han har skrevet flere bøker som siteres hyppig, ikke minst «Homo Sacer» (1998). Boken brukes ofte som en snarvei til å si noe om at vestlige myndigheter svikter mennesker på flukt i det fattige sør. Unnskyld at jeg uttrykker meg vagt, men det er fordi denne kritikken sjelden formuleres presist, den ligger under som en forutsatt fellesforståelse. Samtidig gjenspeiler denne bruken av Agamben at han selv formulerer seg så metaforisk og upresist at han ikke kan konfronteres på noe av det han sier (Johansen 2013). Jeg mistenker at Agamben har blitt en lettvint referanse for noen implisitte men problematiske forutsetninger for migrasjonsforskningen, hvori inkludert de kriminologisk relevante bidragene. Og grunnen til at denne måten å referere på har kunnet bre om seg, er at det blant annet innen kriminologien er en svakt utviklet tradisjon for å konfrontere bruk av såkalt teoretiske referanser.

Jeg skrev et innlegg om kriminalitetens eksistens i NTfK nr. 1, 2014. Der prøvde jeg å rydde litt i forholdet mellom noen av de tekstene som er skrevet om tematikken. Jeg tok for meg Nils Christies bidrag, Leif Petter Olaussens kritikk og Cecilie Høigårds synspunkter. Ved å ta utgangspunkt i påstanden om at kriminalitet er konstruert prøvde jeg å få fram hva slags begreper om sosiale fenome-

* Nicolay B. Johansen er adjunkt ved Institut for Sociologi og Socialt Arbejde, Aalborg Universitet. 
ner som ligger til grunn hos de forskjellige forfatterne. I NTfK nr. 2 - 2014 uttrykker Olaussen sin misbilligelse overfor min gjengivelse av hans posisjon. Det er selvsagt beklagelig, men min lesing av hans bidrag illustrerer mitt problem på opplysende måter.

Sant å si tok jeg noen sjanser i min oppsummering av den sosiologi som kan leses ut av Olaussens bidrag. Jeg tolket ham i beste mening og følte egentlig jeg gjorde ham en tjeneste. Olaussen er i sitt svar opptatt av alle tingene han har skrevet som motsier mine utlegninger. Men problemet var i grunnen ikke at det manglet referanser til den ene og den andre. Problemet var at det var for mange referanser.

Formålet med artikkelen Olaussen reagerer på var som nevnt å sette debatten om kriminalitetens såkalte eksistens i en mer forståelig ramme. Selv om debatten gikk for ca. 10 år siden, virker den stadig forvirrende, særlig for studenter. Påstanden slik den ble fremført av Christie, er litt som Erasmus Montanus hos Holberg, som på overbevisende manér kunne forklare at «morlille er en sten». Fingeren i jorden hadde løst det problemet ganske enkelt om morlille ikke hadde vært så overveldet av hennes hjemkomne sønn. Jeg forstår godt hvorfor Olaussen i sin tid tok til motmæle. Olaussen har ved en rekke anledninger påtatt seg oppdraget å debattere sentrale utgivelser i kriminologien. Kontrære stemmer er helt avgjørende for vitenskapelige fellesskap, så også kriminologien. All ære til ham for det. Men han evnet etter mitt syn ikke å stikke fingeren i jorda.

I kritikken av Christie anvendes en lang rekke klassiske referanser. Men disse innbyrdes svært motsetningsfylte forfatterne settes sammen på en måte som ikke gir ordentlig mening. I sitt første innlegg påkalles blant annet Durkheim, Weber, Searle og Tranøy. Olaussen kunne med tyngde ha anført Durkheim som representant for å se kriminalitet med sin terminologiske nyvinning «enighetskategori». Durkheim så på sosiale fenomener som en særegen form for realitet med «sui generis» karakter. Sosiale fenomener kan bare tilbakeføres til andre sosiale fenomener sa han på et tidspunkt, de kan ikke ha andre årsaker (klimatiske, fysiske, biologiske eller psykologiske). Oversatt til vårt tema, kan kriminalitet som sosialt fenomen bare forstås på bakgrunn av andre sosiale fenomener.

I tillegg trekker Olaussen inn Weber. Man lærer alltid noe når man leser Weber. Men Weber var metodologisk individualist. På dette punktet sto han i direkte motsetning til Durkheim, og de tilhører forskjellige skoleretninger i sosiologien (Collins 1994). Jeg er usikker på hvordan Webers sosiologi kan knyttes til kriminalitetsbegrepet, men enda mer usikker blir jeg av Olaussens ukommenterte sammenstilling av disse herrer. Så hva mener egentlig Olaussen? Spørsmålet blir 
ikke mer opplagt av at han trekker inn filosofen Tranøy og en rekke andre navn i senere arbeider.

Dertil legges også Searles analytiske posisjon, som jeg vil dvele litt ved. Den som leser hans «The construction of social reality» vil raskt se at han er opptatt av å avkle sosiale fenomener deres sui generis egenskaper, han tilbakefører konsekvent etablering av institusjoner til aktive valg begått av konkrete individer. Det er helt i orden å fremføre Searle som teoretisk referanse, men hvordan kan han gjøres kompatibel med Durkheims sosiologi?

Searle har videreutviklet sine begreper om talehandlinger til en hel teori om samfunnet (Searle 1995, Searle 2010). Gjennom mønstre i språkbruk mener han å vise grunnstrukturen i hvordan institusjoner og sosiale arrangementer kommer til. Et av Searles hovedpoeng er å vise hvordan man kan skape virkelighet gjennom erklæringer. Selv om Searle skriver lite om kriminalitet som sådan, kan man med hell overføre hans poenger til de aktuelle diskusjonene, og det på flere måter. Gjennom erklæringer kan man gjøre en handling til kriminalitet. Talehandlinger hviler i hverdagspraksis på en form for bakgrunnskonsensus, og når man erklærer en handling som kriminell utnytter man en felles forståelse av hva kriminalitet er og hva slags handlinger som faller inn under kriminalitet. Erklæringer skaper imidlertid også lover. Her er det institusjonaliserte talehandlinger som finner sted, som må foregå prosessuelt korrekt på en annen måte for å være gyldige. De skaper også en annen type sosial virkelighet, rammevilkår for erklæringer av den foregående typen.

Searle skriver altså om sosiale realiteter på forskjellige måter. Det første eksempelet kunne vært brukt til å støtte Christies prosjekt. Christie ønsker å underminere den moralske kraften i å erklære handlinger som kriminalitet, og Searle bidrar med å vise hvordan erklæringer om slikt kan være kontingente. Samtidig pretenderer Searle å vise hvordan sosiale institusjoner, bredt forstått, blir til. Det ligger altså en teori om sosiale prosesser innbakt i hans arbeider. Det kan hende at denne delen støtter Olaussens poenger.

Et problem med Searles fremstilling er at den er nokså begrenset i eksempelutvalget. Han liker godt å skrive om hva som regnes som et mål i fotball og prosessuelle krav for at et ekteskap skal være gyldig. Eksempelvalgene gjenspeiler at hans perspektiv på sosiale prosesser med utgangspunkt i talehandlinger lett blir for enkelt, eller kanskje ubetydelig, når man tar høyde for kulturelle dimensjoner. Searle viser med slående klarhet hvordan sosiale fenomener blir til, der man kan vise til tydelige viljeshandlinger. Men han kommer til kort i møte med mer komplekse dominansforhold eller hegemoni (Engelstad 1999). Jeg vil legge 
til at hans arbeider er lite egnet til å fange opp bredere kulturelle størrelser som ikke avtegner seg i manifesterbare størrelser som lover og regler.

Mange vil mene at denne begrensningen følger av hva det er mulig å si noe om innenfor vitenskapens rammer. Det forhindrer likevel ikke at det er formulert mer ambisiøse tekster om sosiale fenomener som forsøker å ta inn over seg mer uhåndterlige empiriske størrelser som passende upresist kan kalles kultur, deriblant sosiologiens klassikere.

Så hva er det Olaussen prøver å si? Kan det være at det er allment i sosiologien å operere med begreper om sosiale fenomener som reduserer uklarheter omkring hva som for eksempel skal forstås som kriminalitet i hverdagslivet? Det ville vært et godt argument mot Christies posisjon. Men hos Olaussen fremstår det som om han prøver å hevde at disse forfatterne på en eller annen måte kan settes sammen til en helhetlig sosiologisk fellesnevner. Det er kanskje mulig, jeg skal ikke påberope meg nok kjennskap til alle forfatterskapene Olaussen trekker inn. Men det virker ved gjennomlesing lite overbevisende og ville krevd atskillig mer utfyllende presentasjoner av forfatterne enn det han tilbyr. Det fremstår faktisk nokså usammenhengende. Av mange sosiologier som omtales fremstår det for meg som Olaussen i tale og handling i størst grad uttrykker en slags analytisk sosiologi, slik man finner den hos Searle og Skog i Norge. Det var en vennligsinnet tolkning fra min side.

Svaret i forrige nummer var heller ikke oppklarende. Han gjentar flere av sine referanser til svært forskjelligartede forfattere og sosiologiske posisjoner. Man må etter min oppfatning gjerne være eklektisk. Men det kreves også at man er oppmerksom på om begrepene man bruker kommer i konflikt, som hos Searle og Durkheim. Olaussen gir således fornyet tyngde til behovet for å skrive den artikkelen han kritiserer (men ikke kommenterer).

Mitt bidrag til denne debatten var å hevde at posisjonene i spørsmålet om kriminalitetens eksistens viser til de forskjellige sosiologiske tenkemåter man finner hos partene. Om kriminalitet finnes er først og fremst et tullespørsmål av typen «finnes det noe som er mer enn alt?». Det er fint at spørsmålet likevel har vært en katalysator for få fram forskjellige synspunkter. Toneangivende forfattere i Norden har i en årrekke operert i sosiologiske spenningsfelt som ikke er blitt tematisert. Satt på felles nevner hevder jeg at disse synspunktene kan kokes ned til et spørsmål om hvor (u)bestemt forholdet er mellom kategoriene som benevner kriminalitet og deres praktiske applisering på faktiske handlinger. Men som sosiologiske posisjoner er løsningene på gåten i varierende grad sammenhengende, og hvorfor er det så vanskelig å stikke hull på tullespørsmålet? 
Jeg tror det henger sammen med en utbredt teoriskepsis i kriminologien som fagtradisjon i de nordiske landene. Man kan høre det uformelt, og noen ganger kommer til det skriftlig til uttrykk som hos Høigård i Materialisten (2013). Hun opererer selv med en marxistisk tolkning av Bourdieu. Men hun problematiserer ikke denne posisjonen i arbeidene sine (Høigård 2002). Slik sett representerer hun også en måte å håndtere de overgripende fortellingene på som jeg synes er problematisk. Men det er nokså vanlig å ta lett på sosialteorien. La meg ta et i Nordisk sammenheng mer ufarlig eksempel:

Da jeg for kort tid siden var på seminar i forbindelse med et bokprosjekt, var det en annen deltager som under forhandlingene sa at han ville bygge videre på det Zygmunt Bauman og Norbert Elias sto for. Det foreligger i skrivende stund ikke noe skriftlig resultat av denne personens erklæringer, men jeg ser ikke bort fra at resultatet kan bli interessant. Det bør imidlertid nevnes at Bauman faktisk gikk til krig mot sosiologien som sådan i en av de mest aktuelle bøkene for sakens anledning, og at Baumans prosjekt uttrykkelig var å erstatte sosiologien med en «før-sosiologisk moralteori». Anledningen var en diskusjon om straff og «de andre» med utgangspunkt i Baumans modernitetsbegrep (se Eriksson 2015 under utgivelse). Etter litt fram og tilbake var vi kommet til felles forståelse om at vi skulle konsentrere oss om det vi kalte «nærhetstesen» slik den blant annet fremkommer i boken «Modernity and Holocaust» (Bauman 1989). Nærhetstesen er gjenkjennelig for de fleste nordiske kriminologer, ved at det er en måte å fremheve sosial avstand, eller mangel på slik, som det mest avgjørende trekk ved samfunnsorganismen. Den gjenfinnes i forskjellige former hos blant annet Christie og Balvig, nylig også hos Engdahl (2011).

Bauman hevder at moral kommer før det sosiale. Det er som sådan en erklæring om at sosiologien ikke kan hjelpe oss til det som er hans hovedanliggende, nemlig å bidra til en moral som skal forhindre at Holocaust kan skje igjen. Hans nærhetstese skal således forstås som en teori i direkte konkurranse med det han identifiserer som sosiologien. Han bruker ikke mye plass på å redegjøre for hvordan han forstår Elias, men det er nettopp Elias som løftes fram som skyteskive. Når Bauman skal ta avstand fra sosiologien, bruker han Elias som symbol for hele denne tradisjonen.

Er det da rimelig å bygge videre på det Elias og Bauman har skapt, når man snakker om å straffe De andre? Jeg er ikke i tvil om at det går an å diskutere disse to forfatternes arbeider konstruktivt opp mot hverandre. Men det krever i det minste en kommentar, og dessuten kanskje at polariteten mellom de to forfatterne tematiseres med litt mer enn ett avsnitt. Hvorfor det? Jo fordi ellers gjenfortelles 
de to posisjonene på en måte som ikke rettferdiggjør at man refererer til dem i det hele tatt.

Hvorfor har vi teori? Det er for å hjelpe oss med å tenke. Å tenke om forbindelser og sammenhenger krever trening i å holde abstrakte størrelser fra hverandre. Samfunnsteori, og annen teori, hjelper oss med å sortere mønstre i måter å tenke sammenhenger. Det er for eksempel forskjeller mellom Christies måte å tenke om nærhet og avstand og Baumans måte å gjøre det. Men det går an å se likheter i tankemønstre. Så hvis vi aksepterer at det finnes noe slikt som nærhetssosiologi, vil det nok være rimelig å inkludere begge disse her. Det vil i alle fall jeg hevde, etter å ha tatt for meg denne type sosiologi i min PhD-avhandling (der riktignok Bauman ikke er omtalt, se nedenfor).

Et annet spørsmål er hva man skal kalle Elias' sosiologi. I den samme avhandlingen ville jeg identifisere en særlig tradisjon i tenkingen omkring sosial kontroll med utgangspunkt i Durkheim, som en kontrast til avstandssosiologien. Her tok jeg utgangspunkt i Durkheims begrep om kollektive representasjoner og identifiserte en litt annen tenketradisjon som fremhevet kulturelt overførte kategorier og klassifikasjonsskjemaer (Johansen 2008). Jeg vil hevde at Elias tilhører denne tradisjonen (Johansen 2010). Dette til tross for at Elias selv var svært kritisk til Durkheim (Elias 1994, se introduksjonen).

Disse grepene var ikke opplagte, og man kan saktens være uenig i dem. Det som er mitt hovedpoeng er at det å bruke såkalte teoretiske forfattere, eller en hver som ønsker å si noe om sammenhenger mellom sosiale fenomener med et visst abstraksjonsnivå, må tematisere måten de gjør dette på. Min navnløse forfatterkollega kan gjerne diskutere Elias og Bauman som samlet teoretisk størrelse. De har sikkert felles synspunkter og andre berøringsfelter. Men det vil etter min oppfatning være utilbørlig å gjøre dette dersom spenningen mellom de to ikke blir kommentert. Og for egen del vil jeg hevde at det rimer svært dårlig med at Bauman brukte nettopp Elias til å ta avstand fra sosiologien.

Når jeg kaller spørsmålet om kriminalitetens eksistens for et tullespørsmål er det først og fremst fordi det er både sant og ikke sant, litt ettersom man ser det. Spørsmål som har den type svar er ofte feil stilt. Antagelig er påstanden slik den er fremsatt av Christie heller ikke vitenskapsteoretisk eller sosiologisk motivert. Det er først og fremst en retorisk gest myntet på den kriminalpolitiske offentlighet. Han har ønsket å slå en kile inn i en etablert forståelse av kriminalitet som sosialt bestemt og udiskutabelt fenomen. Men i tillegg har spørsmålet gitt en anledning til å sette måter å tenke sosiologisk opp mot hverandre og således adressere betydningen av å reflektere omkring de sosiologiske tanketradisjoner vi opererer innenfor. Det er i det minste av det gode. 
Jeg mener det er for mye lettvint bruk av sosiologisk kjernelitteratur. Det ligger til samfunnsvitenskapens kodeks at man er etterrettelig i bruk av metode. Hvorfor skal det være mindre viktig å være grundig når man gjør bruk av forfattere som tilbyr større sammenhenger?

Noen ganger skjuler lettvint omgang med teori at forfatteren ønsker å legitimere en posisjon, som ved bruken av Agamben omtalt innledningsvis. Jeg tror ikke Olaussen er ute i slike ærender. Samfunnsvitenskapelig arbeid er av og til å gjøre resonnementer mulige, gjennom bruk av generaliserende diskusjoner. Det behøver ikke være galt, men slik bruk av teori kan også misbrukes. Det åpner en dør mellom akademisk og politisk virksomhet.

\section{Litteratur}

Agamben, G. (1998). Homo sacer: sovereign power and bare life. Stanford, California, Stanford University Press.

Bauman, Z. (1989). Modernity and the Holocaust. Cambridge, Polity Press.

Collins, R. (1994). Four sociological traditions. New York, Oxford University Press.

Elias, N. (1994). The civilizing process. Oxford, Blackwell.

Engdahl, O. (2011). Hur fungerar social kontroll? . Social kontroll: övervakning, disciplinering och självreglering. O. Engdahl and B. Larsson. Malmö, Liber.

Engelstad, F. (1999). Makt i John searles teori om Sosiale institusjoner. Om Makt: teori og Kritikk. F. Engelstad. Oslo, Ad Notam Gyldendal.

Eriksson, A., Ed. (2015). Punishing the Other. London, Routledge.

Høigård, C. (2002). Gategallerier. Oslo, Pax.

Høigård, C. (2013). «Kritisk Teori.» Materialisten (1).

Johansen, N.B. (2008). Sosial kontroll i byer: to tradisjoner etter Durkheim og Tönnies. Oslo, Universitetet i Oslo.

Johansen, N.B. (2010). «To tradisjoner i tenkingen om sosial kontroll.» Sosiologisk Arbok(1): 22.

Johansen, N.B. (2013). Governing the Funnel of Expulsion. The Borders of Punishment: criminal justice, citizenship and social exclusion. A.K. Franko and M. Bosworth, Oxford, Oxford University Press.

Searle, J.R. (1995). The construction of social reality. London, Allen Lane.

Searle, J.R. (2010). Making the social world: the structure of human civilization. Oxford, Oxford University Press. 